\title{
Rice Husk Ash and Fly Ash Effects on the Mechanical Properties of Concrete
}

\author{
Naraindas Bheel \\ Civil Engineering Department \\ Hyderabad College of Science \& \\ Technology \\ Sindh, Pakistan \\ naraindas04@gmail.com \\ Hyder Bux Lashari \\ Hyderabad College of Science \& \\ Technology \\ Sindh, Pakistan \\ nbprinces12@gmail.com
}

\author{
Muneer Ali Jokhio \\ Civil Engineering Department \\ Hyderabad College of Science \& \\ Technology \\ Sindh, Pakistan \\ jokhiomuneer08@gmail.com \\ Muhammad Imran Qureshi \\ Hyderabad College of Science \& \\ Technology \\ Sindh, Pakistan \\ muhammadimranqureshi276@gmail.com
}

\author{
Javed Ahmed Abbasi \\ Hyderabad College of Science \& \\ Technology \\ Sindh, Pakistan \\ javikalhoro77@gmail.com
}

\author{
Abdul Salam Qureshi \\ Hyderabad College of Science \& \\ Technology \\ Sindh, Pakistan \\ qureshi.salam@gmail.com
}

\begin{abstract}
Cement production involves high amounts of energy consumption and carbon dioxide emissions. Pakistan is facing a serious energy crisis and cement's cost is increasing. In addition, landfilling of potential concrete components can lead to environmental degradation. The use of waste as cement replacement not only reduces cement production cost by reducing energy consumption, but it is also environmentally friendly. The purpose of this study is to analyze the characteristics of concrete by partially replacing cement with Rice Husk Ash (RHA) and Fly Ash (FA). This study is mainly focused on the performance of concrete conducting a slump test, and investigating indirect tensile and compressive strength. Cement was replaced with RHA and FA by 5\% (2.5\% RHA + $2.5 \%$ FA), $10 \%$ (5\% RHA + 5\% FA), $15 \%$ (7.5\% RHA + 7.5\% FA) and $20 \%(10 \%$ RHA $+10 \%$ FA) by weight. Ninety concrete samples were cast with mix proportions of $1: 2: 4$ and 0.55 water/cement ratio. Cube and cylindrical samples were used for measuring compressive and split tensile strength respectively, after 7 and 28 days. The results showed that after 28 days, the $\mathbf{5 \%}$ RHA $+\mathbf{5 \%}$ FA sample's compressive strength was enhanced by $16.14 \%$ and its indirect tensile strength was improved by $15.20 \%$ compared to the conventional sample. Moreover, the sample's slump value dropped as the content of RHA and FA increased.
\end{abstract}

Keywords-rice husk ash; fly ash; cement replacement; increased strength; reduced environmental pollution

\section{INTRODUCTION}

Concrete is extensively used in artificial materials. Due to its adaptability and relative profitability, it is considered as a competitive building material [1]. Concrete consists of cement, aggregates, and water. Aggregates comprise about $75-80 \%$ of the total volume of concrete, affecting the properties of fresh and hardened concrete and its performance [2-3]. Cement manufacturing has some disadvantages, such as high production cost and energy requirements. Cement production also leads to mass emissions of $\mathrm{CO}_{2}$ and other greenhouse gases. The production of one tone of cement emits 1-1.25 tons of $\mathrm{CO}_{2}$ [4-6], requires about $1.60 \mathrm{MWh}$ of energy, and thus it is considered as an expensive and non-environment friendly process [7].

According to [8], human activity produces more than 5,000 tons of solid waste per year, which include ingredients such as silica fumes, RHA [9, 10], FA, and corncob ash. Considerable savings in cost and energy consumption could be achieved by utilizing these by-products as partial cement replacements [11]. The utilization of agricultural waste such as RHA, sugarcane bagasse ash [12], waste glass powder, FA, and millet husk ash [13], in order to reduce cost, waste and $\mathrm{CO}_{2}$ emissions, was investigated in $[14,15]$. Routine treatments of agricultural and industrial waste are a major concern. RHA and FA are agricultural by-products [16-18], and they are considered hazardous as they are usually burnt $[19,20]$. RHA and FA are highly pozzolanic in nature, and they could be utilized as Portland cement replacements. Due to their high silica content and low cost, these materials have a high potential in the production of secondary cementing material [21]. The annual production of rice husk is about 120 million tons [22]. RHA has a silica content of $85 \%$, called amorphous silica, and it could be utilized as a cementitious material in concrete [23, 24]. Under industrial conditions, FA is generated by burning coal. Nowadays, with the use of pollution control equipment such as electrostatic precipitators or other filtering equipment, FA is captured before flue gases enter the chimney of a coalfired power plant. About $43 \%$ of FA from coal-fired power plants in USA is collected and utilized as a cementitious material in the making of concrete [25]. The main goal of this research is to evaluate the properties of fresh, physical and hardened concrete using RHA and FA as cement replacements. 


\section{RESEARCH METHODOLOGY}

The properties of fresh and hardened concrete were studied for five concrete mixtures: $0 \% \mathrm{RHA}+0 \% \mathrm{FA}$, $2.5 \% \mathrm{RHA}+2.5 \% \mathrm{FA}, \quad 5 \% \mathrm{RHA}+5 \% \mathrm{FA}, \quad 7.5 \% \mathrm{RHA}+7.5 \% \mathrm{FA}$, and $10 \%$ RHA $+10 \%$ FA. Ninety concrete samples were prepared, in 60 cylinders and 30 prisms, with 1:2:4 mix proportions, 0.55 water/cement ratio and were cured for 7 and 28 days. In order to determine the characteristic strength of concrete samples, they were tested on an Universal Testin Machine (UTM), and the ASTM C192 Standard was met. Concrete cubes $(100 \times 100 \times 100 \mathrm{~mm})$ were used to measure compressive strength, and cylinder samples $(200 \times 100 \mathrm{~mm})$ were used for determining indirect tensile strength. Similarly, the density and the water absorption of the samples were measured after 28 days. Three concrete samples were cast for each ratio, and the final result was determined as the mean of the three samples. The study was conducted in the laboratory of Concrete Technology, H.C.S.T Hyderabad, Sindh, Pakistan [26].

\section{MATERIALS USED}

\section{A. Cement}

Locally available Ordinary Portland Cement, under the brand name "Pakland", was utilized as a binding material. Its experimental physical properties are shown in Table I.

TABLE I. PHYSICAL PROPERTIES OF CEMENT

\begin{tabular}{|c|c|c|}
\hline S.N. & Tests & Results \\
\hline 01 & Normal consistency & $33 \%$ \\
\hline 02 & Initial setting time & $50 \mathrm{~min}$ \\
\hline 03 & Final setting time & $260 \mathrm{~min}$ \\
\hline
\end{tabular}

\section{B. Fine and Coarse Aggregates}

The aggregates used are locally available in the region of Hyderabad. Hill sand passing through \#4 sieve was used as fine aggregates, and $20 \mathrm{~mm}$ crushed stone was used as coarse aggregates. The properties of the laboratory test results of aggregates are shown in Table II.

TABLE II. PHYSICAL PROPERTIES OF AGGREGATES

\begin{tabular}{|c|c|c|c|}
\hline S.N. & Properties & Fine aggregates & Coarse aggregates \\
\hline 01 & Fineness modulus & 2.26 & --- \\
\hline 02 & Sieve analysis & Zone-II & --- \\
\hline 03 & Water absorption & $1.80 \%$ & $1.20 \%$ \\
\hline 04 & Specific gravity & 2.67 & 2.63 \\
\hline 05 & Bulk density & $1231 \mathrm{~b} / \mathrm{ft}^{3}$ & $102 \mathrm{lb} / \mathrm{ft}^{3}$ \\
\hline
\end{tabular}

\section{Rice Husk Ash}

The husk of rice was collected from the region of Hyderabad. After its collection, the rice husk was burnt under uncontrolled burning temperature to produce ash. This ash was sieved through \#30 sieves.

\section{Fly Ash}

The FA, generated in the form of very fine powder passing from \#30 sieves, was collected from the Lakhra coal power plant. The Lakhra coal power plant generates about 2 million tons of FA annually, which are dumped in a landfill. Utilizing the FA produced in the power plant as a cement replacement could reduce this.

\section{E. Water:}

Potable water was used.

\section{RESULTS AND DISCUSSION}

\section{A. Workability of Fresh Concrete}

The highest slump value measured was $42 \mathrm{~mm}$ for the $0 \%$ RHA $+0 \%$ FA samples, while the lowest was $20 \mathrm{~mm}$ for the $10 \%$ RHA $+10 \%$ FA mixture. The slump value reduced with the rise of RHA and FA content, as shown in Figure 1.

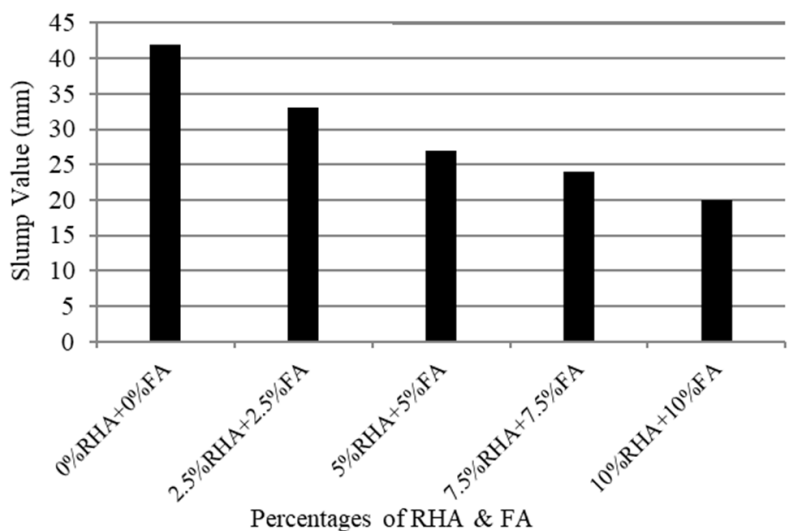

Fig. 1. Workability of fresh concrete

\section{B. Density of Concrete}

The density of the samples was measured on the $28^{\text {th }}$ day. The conventional $(0 \%$ RHA $+0 \%$ FA) sample had the highest density $\left(2392 \mathrm{~kg} / \mathrm{m}^{3}\right)$, while the $10 \% \mathrm{RHA}+10 \% \mathrm{FA}$ had the lowest $\left(2288 \mathrm{~kg} / \mathrm{m}^{3}\right)$. The density of the concrete reduced as the RHA and FA increased, as shown in Figure 2.

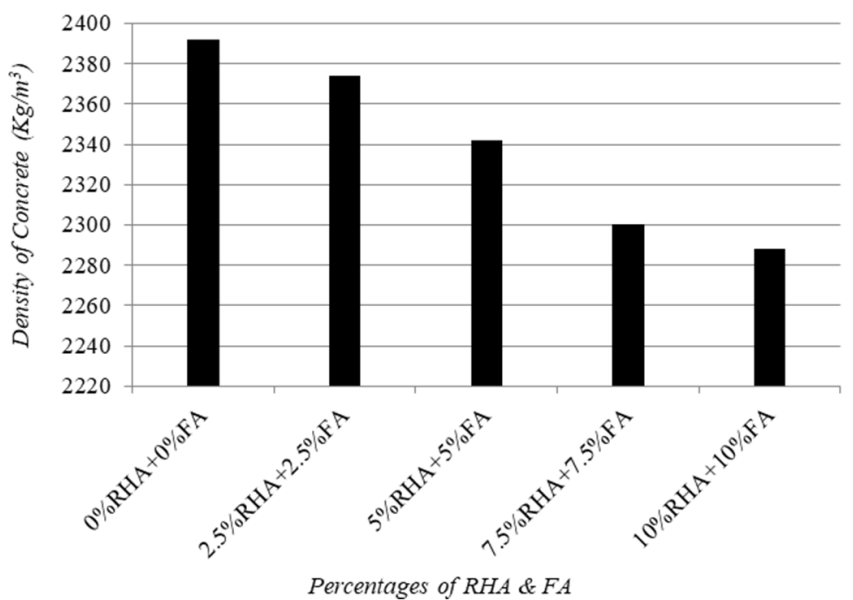

Fig. 2. Density of concrete

\section{Water Absorption}

The water absorption of the concrete samples was analyzed on the $28^{\text {th }}$ day. The highest water absorption was found to be $4.65 \%$ for the $10 \%$ RHA $+10 \%$ FA sample, while the lowest was 
$2.89 \%$ for the conventional sample. The water absorption of concrete augmented with the rise of RHA and FA as shown in Figure 3.

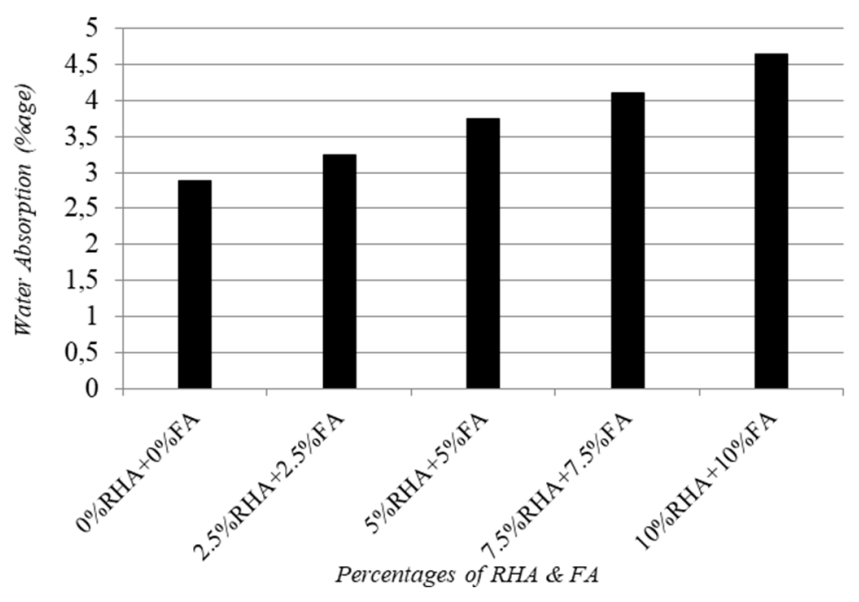

Fig. 3. Water absorption of concrete

\section{Compressive Strength}

The cubical samples $(100 \times 100 \times 100 \mathrm{~mm})$ were used for investigating the compressive strength of concrete. Compressive strength was enhanced by $14.5 \%$ and $16.14 \%$ in comparison with the conventional mix when cement was replaced by $5 \% \mathrm{RHA}+5 \% \mathrm{FA}$, while it was reduced by $13.7 \%$ and $12.90 \%$ for the $10 \%$ RHA $+10 \%$ FA sample, on the $7^{\text {th }}$ and the $28^{\text {th }}$ day respectively as shown in Figure 4.

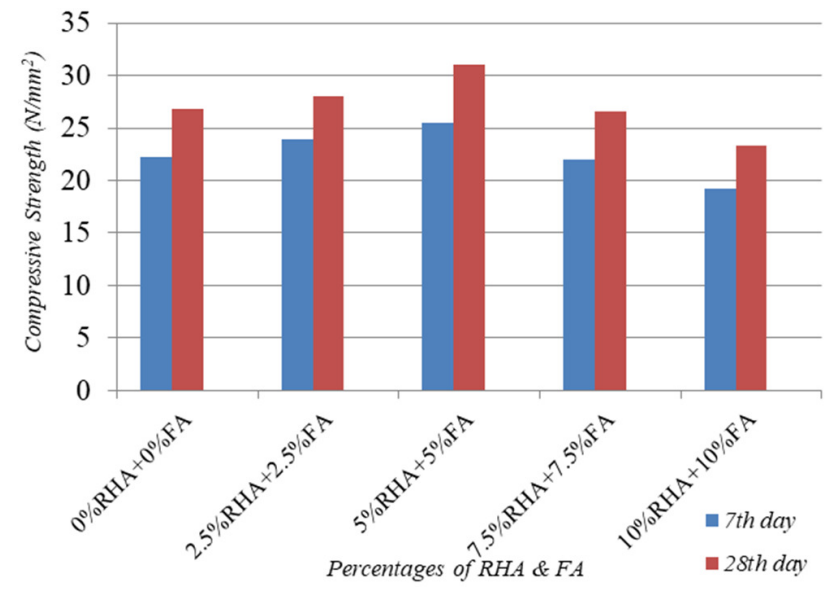

Fig. 4. Compressive strength of concrete

\section{E. Indirect Tensile Strength of Concrete}

The cylindrical samples $(100 \times 200 \mathrm{~mm})$ were used for determining split tensile strength. The indirect tensile strength improved by $11.4 \%$ and $15.20 \%$ in comparison with the conventional concrete for the 5\%RHA $+5 \%$ FA sample, while it reduced by $19.6 \%$ and $9.30 \%$ for the $10 \% \mathrm{RHA}+10 \% \mathrm{FA}$ sample, on the 7 th and 28 th day respectively, as shown in Figure 5.

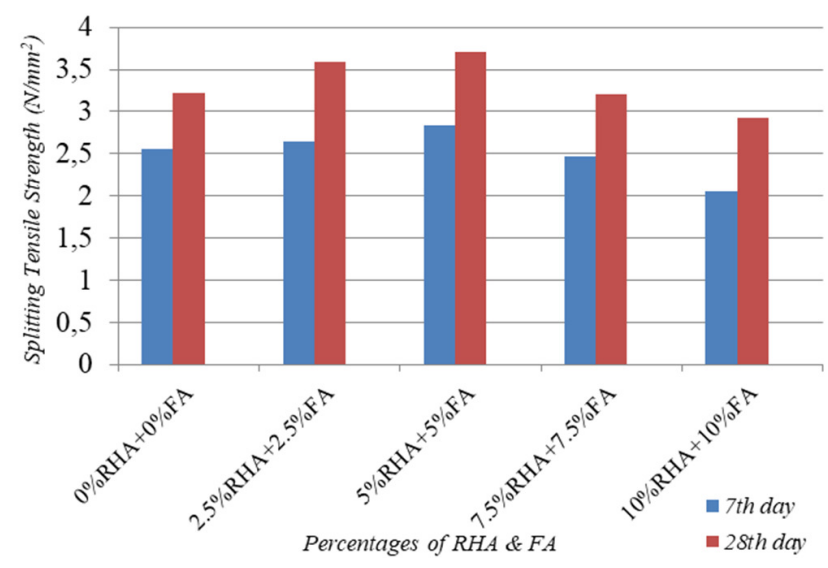

Fig. 5. Split tensile strength of concrete

\section{CONCLUSION}

Based on the experimental results obtained, it is concluded that the highest measured slump value was $42 \mathrm{~mm}$ for the conventional sample, while the lowest was $20 \mathrm{~mm}$ for the $10 \%$ RHA $+10 \% \mathrm{FA}$. The highest density measured after 28 days was $2392 \mathrm{~kg} / \mathrm{m}^{3}$ for the conventional sample, while the lowest was $2288 \mathrm{~kg} / \mathrm{m}^{3}$ for the $10 \% \mathrm{RHA}+10 \% \mathrm{FA}$. The optimum water absorption measured after 28 days was $4.65 \%$ for the $10 \%$ RHA $+10 \%$ FA sample, while the lowest was $2.89 \%$ for the conventional sample. Compressive strength improved by $14.5 \%$ and $16.14 \%$ compared to the conventional mix when cement was replaced by $5 \% \mathrm{RHA}$ and $5 \% \mathrm{FA}$, while it was reduced by $13.7 \%$ and $12.90 \%$ in the $10 \% \mathrm{RHA}+10 \% \mathrm{FA}$ sample, measured on the $7^{\text {th }}$ and the $28^{\text {th }}$ day respectively. Indirect tensile strength was enhanced by $11.4 \%$ and $15.20 \%$ compared to the conventional sample when cement was replaced by 5\% RHA and 5\% FA, while it reduced by $19.6 \%$ and $9.30 \%$ for the $10 \%$ RHA $+10 \%$ FA sample on the $7^{\text {th }}$ and the $28^{\text {th }}$ day respectively.

In conclusion, optimum hardened properties were obtained by using 5\% RHA and 5\% FA as cement replacement material in concrete.

\section{REFERENCES}

[1] S. Ghosal, S.C. Moulik, "Use of rice husk ash as partial replacement with cement in concrete-a review", International Journal of Engineering Research, Vol. 4, No. 9, pp. 506-509, 2015

[2] A. M. Neville, J. J. Brooks, Concrete technology, Pearson Education Asia Pte Ltd, 2008

[3] M. Alexander, S. Mindness, Aggregates in concrete, Taylor and Francis, 2005

[4] P. V. Naidu, P. K. Pandey, "Replacement of cement in concrete", International Journal of Environmental Research and Development, Vol. 4, No. 1, pp. 91-98, 2014

[5] Z. H., Shaikh, A. Kumar, M. A., Kerio, N. Bheel, A. A., Dayo, A. W. Abro, "Investigation on selected properties of concrete blended with maize cob ash", $10^{\text {th }}$ International Civil Engineering Conference, Karachi, Pakistan, February 23-24, 2019

[6] N. Bheel, R. A. Abbasi, S. Sohu, S. A. Abbasi, A. W. Abro, Z. H. Shaikh, "Effect of tile powder used as a cementitious material on the mechanical properties of concrete”, Engineering, Technology \& Applied Science Research, Vol. 9, No. 5, pp. 4596-4599, 2019

[7] A. M. Neville, Properties of concrete, Pearson Education Asia Pte Ltd, 2000 
[8] V. W. Ramasamy, "Compressive strength and durability properties of rice husk ash concrete", KSCE Journal of Civil Engineering, Vol. 16, No. 1, pp. 93-102, 2012

[9] N. Bheel, A. W. Abro, I. A. Shar, A. A. Dayo, S. Shaikh, Z. H. Shaikh, "Use of rice husk ash as cementitious material in concrete", Engineering, Technology \& Applied Science Research, Vol. 9, No. 3, pp. 4209-4212, 2019

[10] N. Bheel, S. L. Meghwar, S. A. Abbasi, L. C. Marwari, J. A. Mugeri, R. A. Abbasi, "Effect of rice husk ash and water-cement ratio on strength of concrete", Civil Engineering Journal, Vol. 4, No. 10, pp. 2373-2382, 2018

[11] J. P. Broomfield, Corrosion of steel in concrete: understanding, investigation and repair, CRC Press, 2006

[12] A. A. Dayo, A. Kumar, A. Raja, N. Bheel, Z. H. Shaikh, "Use of sugarcane bagasse ash as a fine aggregate in cement concrete", Engineering Science and Technology International Research Journal, Vol. 3, No. 3, pp. 8-11, 2019

[13] N. D. Bheela, F. A. Memon, S. L. Meghwar, A. W. Abro, I. A. Shar, "Millet husk ash as environmental friendly material in cement concrete", $5^{\text {th }}$ International Conference on Energy, Environment and Sustainable Development, Mehran UET Jamshoro, Pakistan, November 14-16, 2018

[14] R. R. Hussain, T. Ishida, "Critical carbonation depth for initiation of steel corrosion in fully carbonated concrete and development of electrochemical carbonation induced corrosion model", International Journal of Electrochemical Science,Vol. 4, No. 8, pp. 1178-1195, 2009

[15] N. Kad, M. Vinod, "Review research paper on influence of rice husk ash on the properties of concrete", International Journal of Research, Vol. 2, No. 5, pp. 873-877, 2015

[16] M. Anwar, T. Miyagawa, M. Gaweesh, "Using rice husk ash as a cement replacement material in concrete", Waste Management Series, Vol. 1, pp. 671-684, 2000

[17] S. D. Nagrale, H. Hajare, P. R. Modak, "Utilization of rice husk ash", International Journal of Engineering Research and Applications, Vol. 2, No. 6, pp. 1-5, 2012

[18] I. B. Ologunagba, A. S. Daramola, A.O. Aliu, "Feasibility of using rice husk ash as partial replacement for concrete", International Journal of Engineering Trends and Technology, Vol. 30, No. 5, pp. 267-269, 2015

[19] A. N. Givi, S. A. Rashid, F. N. A. Aziz, M. A. M. Salleh, "Contribution of rice husk ash to the properties of mortar and concrete: a review", Journal of American Science, Vol. 6, No. 3, pp. 157-165, 2010

[20] N. Bheel, S. L. Meghwar, S. Sohu, A. R. Khoso, A. Kumar, Z. H. Shaikh, "Experimental study on recycled concrete aggregates with rice husk ash as partial cement replacement", Civil Engineering Journal, Vol. 4, No. 10, pp. 2305-2314, 2018

[21] H. B. Mahmud, N. A. A. Hamid, K. Y. Chin, "Production of high strength concrete incorporating an agricultural waste-rice husk ash", 2nd International Conference on Chemical, Biological and Environmental Engineering, Cairo, Egypt, November 2-4, 2010

[22] H. T. Le, K. Siewert, H. M. Ludwig, "Alkali silica reaction in mortar formulated from self-compacting high performance concrete containing rice husk ash", Construction and Building Materials, Vol. 88, pp. 10-19, 2015

[23] N. P. Hasparyk, P. J. Monteiro, H. Carasek, "Effect of silica fume and rice husk ash on alkali-silica reaction", Materials Journal, Vol. 97, No. 4, pp. 486-492, 2000

[24] K. Sakr, "Effects of silica fume and rice husk ash on the properties of heavy weight concrete", Journal of Materials in Civil Engineering, Vol. 18, No. 3, pp. 367-376, 2006

[25] V. Goud, N. Soni, G. Varma, K. Kushwah, S. Chaurasia, V. Sharma, "Partial replacement of cement with fly ash in concrete and its effect", IOSR Journal of Engineering, Vol. 6, No. 10, pp. 69-75, 2016

[26] N. D. Bheel, S. A. Abbasi, S. L. Meghwar, F. A. Shaikh, "Effect of human hair as fibers in cement concrete", International Conference on Sustainable Development in Civil Engineering, Jamshoro, Pakistan, November 23-25, 2017 